\title{
Miranda
}

Revue pluridisciplinaire du monde anglophone /

Multidisciplinary peer-reviewed journal on the English-

speaking world

19 | 2019

Rethinking Laughter in Contemporary Anglophone Theatre

\section{Three Ballerinas: A Moving Sketch (Jellybean Dance Collective, 2019)}

An interview with dancer and choreographer Victoria Niblett

Nathalie Vincent-Arnaud

\section{(2) OpenEdition}

\section{Journals}

Electronic version

URL: http://journals.openedition.org/miranda/20770

DOI: $10.4000 /$ miranda.20770

ISSN: 2108-6559

\section{Publisher}

Université Toulouse - Jean Jaurès

Printed version

Date of publication: 7 October 2019

Electronic reference

Nathalie Vincent-Arnaud, "Three Ballerinas: A Moving Sketch (Jellybean Dance Collective, 2019)", Miranda [Online], 19 | 2019, Online since 09 October 2019, connection on 16 February 2021. URL: http://journals.openedition.org/miranda/20770 ; DOI: https://doi.org/10.4000/miranda.20770

This text was automatically generated on 16 February 2021

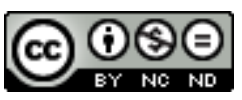

Miranda is licensed under a Creative Commons Attribution-NonCommercial-NoDerivatives 4.0 International License. 


\title{
Three Ballerinas: A Moving Sketch (Jellybean Dance Collective, 2019)
}

An interview with dancer and choreographer Victoria Niblett

\author{
Nathalie Vincent-Arnaud
}

1 The performance Three Ballerinas: A Moving Sketch given by some members of the Alabamian company Jellybean Dance Collective (https://victorianiblett.com/ jellybeandancecollective; https://vimeo.com/353062954) was one of the highlights of the 15th international F. Scott Fitzgerald Society conference on "Place and Placelessness" that took place at the Université Toulouse-Jean Jaurès from 24th to 29th June 2019, organized by Pascal Bardet, a Fitzgerald scholar and member of the Society (https://cas.univ-tlse2.fr/place-and-placelessness-the-15th-international-f-s-

fitzgerald-society-conference-600327.kjsp).

2 Victoria Niblett, founder of the company, dancer and choreographer, kindly agreed to answer some questions about her piece which focuses on one of the most fascinating figures in American literature and artistic life, whose pioneering role and legacy were duly emphasized during the conference: Zelda Fitzgerald.

Nathalie Vincent-Arnaud: How did you come to be connected with the Fitzgerald Association and the Fitzgerald conference that took place in Toulouse last June?

Victoria Niblett: This work, Three Ballerinas: A Moving Sketch is a part of a project called The Sweet Home Storytelling Dance Series that I created in the summer of 2018 in partnership with the ALABAMA 200 organization. This organization's mission is to commemorate the bicentennial of Alabama's statehood and inclusion into the United States of America. My role in this celebration is that I take significant historical events, people of interest, and natural heritage in the state of Alabama and translate their importance into movement and dance. The goal is that audiences will be able to connect and engage with these narratives in a unique and interdisciplinary way. In my research for this exciting time in Alabama's history, I was immediately inspired to dive deeper into the legacy of Alabama native Zelda Fitzgerald and dance her story. I presented this idea for a site-specific performance to the F. Scott and Zelda Fitzgerald Museum in Montgomery, Alabama, and they invited us to debut this performance on 
December 14, 2018 where Dr. Kirk Curnutt, the Executive Director of the F. Scott Fitzgerald Society saw the performance and facilitated positive discussion and inquiry on Zelda's legacy and how we were translating it through one of her sketches into dance. My dancers and I were able to dance as a 'moving' exhibit throughout the Museum and interact with the space and energy of the only museum in the world dedicated to the lives and legacies of the Fitzgeralds. We also found it incredibly inspiring that this museum is also the site of their last extant home as a family and where they wrote portions of their respective novels, Save Me the Waltz and Tender is the Night. Ultimately, after this performance, we were invited to the F. Scott Fitzgerald Society's 15th International Conference in Toulouse this past June.

NVA: What are your background and main sources of inspiration as a dancer and choreographer?

VN: I have been training in dance since the age of two, and continue to dedicate my time to learning more about my craft through classes and intensives.

I recently graduated Summa Cum Laude from the University of Alabama with a degree in dance and public relations and an honors college distinction that allowed me to take classes through the University of Alabama Law School while an undergraduate. During college, I balanced my academic endeavors with performances on UA's official dance team the Crimson Cabaret, the state's premiere student-produced concert Dance Alabama!, and the Alabama Repertory Dance Theatre company. While a part of the Alabama Repertory Dance Theatre Company, I was cast in works by Quianping Guo of the Vaganova Ballet Academy, Lawrence Jackson of the Cleo Parker Robinson company, Natosha Washington of The Penguin Lady Dance Collective, and more. In my final semester of undergraduate study, I presented award-winning research in Choreography and United States Copyright Law for the Research and Creative Activity Conference and collaborated with Sarah M. Barry and Andrew Raffo-Dewar on the Sonic Frontier Series concert.

After graduating top of my class, I was able to travel to New York to study floor work, partnering, and contemporary movement under Shannon Gillen and her visionary dance theatre company, VIM VIGOR.

I was honored to be accepted as a full-time professional student at the Martha Graham School of Contemporary Dance in New York and recently performed with the school's intensive program in "Ritual to the Sun" from Martha Graham's 1981 ballet, Acts of Light.

I launched the Jellybean Dance Collective in December of 2018, and am the current director of a budding interdisciplinary moving arts company focused on storytelling and arts integration. I am also a current company dancer for Formations, directed by Whitney Renfroe, and debuted with the company this past September in the multidisciplinary arts show, Permanence.

I can also be found at national and international dance conventions, festivals, workshops, and performances. Most recently, I traveled to Hermosillo, Mexico for the Danzética convention where I teach modern and contemporary movement and Montrouis, Haiti to teach tap and creative movement classes. I love to inspire young artists to discover their dreams, and aim to give them the tools and confidence to achieve them. With my choreography and teaching residency at Encore Performance Company in Birmingham, Alabama, my students have won regional and national 
titles in dance and have gained special recognition for technical execution and choreography.

I'm currently in my first semester of my master's degree studies at Johns Hopkins University where I am pursuing a Master of Arts in Cultural Heritage Management and Nonprofit Management. I am focusing on intangible heritage practices and a space of the cultural heritage sector that allows me to be a part of building the bridges that connect our world and place value on participating in the exchange of art, culture, history, and humanity.

These aforementioned values serve as my biggest choreographic inspirations, and I like to focus on universal truths and human connectivity in my work. In my creative endeavors, I like to focus on how to expand the specific or personal into the universal because I believe while our experiences are vastly different and our backgrounds transcend continents and time, most often there are points or commonalities of universal wants and needs for expression, connection, and understanding within every story. For example, in my dance of Zelda's story, I believe there's something all of us can understand or relate to - whether it's me choreographing as a third person narrator, or one of my dancers dancing as Zelda's experience of her own mind, or an audience member watching and experiencing the work, I believe there are universal ideas situated within the specific and biographical account of Zelda's life that can transcend the lines of her own story and touch our own. Because of this focus, my work often requires an active audience involved in inquiry, discussion, and consideration of the work and its greater significance.

In creation of the work, I often use words and literature to generate movement phrases and think about the body as a translator for these words in a universal language. I also long to use the body as a map for big emotional experience that can't quite be translated into words. For example what would exhilaration look like on the body? How would it move? These challenges inspire me to move, and I use these ideas to create most of the works I present.

NVA: Your website mentions that your company, Jellybean Dance Collective, was named after Zelda Fitzgerald, more particularly after the dance group she was involved in at some point. Do you know why Zelda's dance group was called The Jellybeans in the first place?

VN: I'm unclear of Zelda's motivations, but historically and according to National Geographic, jelly beans had become a very popular penny candy by the late 19th century so they would have been popular enough by Zelda's childhood to be recognizable. Webster's dictionary included "jelly bean" by 1905, and by 1915 the word "jelly bean" even became popular slang for a worthless, weak male. In 1920, F. Scott Fitzgerald's short story, "The Jelly-bean" featured a male character with these uninspiring characteristics. I imagine this pejorative use for the word has something to do with why Zelda's group was called The Jellybeans though I don't know for sure. We were of course attracted to being called the Jellybean Dance Collective because of Zelda's dance group, but beyond that we found inspiration in the variance, diversity, and whimsy of the candy. In my research, I also found that while this is a relatively new candy, it combines candy making practices inspired from 1600s France and all the way back to Middle Eastern biblical times. This idea of time transcendence and tradition was appealing to me. I was also inspired by the idea of the accessibility of the "penny candy" which was an affordable sweet for working class Americans that expanded on the look of a common bean. Beans were things many were growing in 
their own gardens and knew familiarly, but the jelly bean was just making life sweeter!

NVA: On the website you also describe yourself as «a history and literature lover ». Was your interest for Zelda Fitzgerald originally triggered by Zelda the dancer, Zelda the writer, or both?

VN: I'd say my interest and passion for Zelda Fitzgerald was triggered by Zelda the woman. I found her enchanting as so many people do because of her vibrancy, no matter her creative endeavor, but beyond this I found connection to her as a strong, Southern woman and interdisciplinary artist first. I remember reading F. Scott Fitzgerald's The Great Gatsby in high school and being enthralled by it, but I had a very unique experience of discovering Zelda because as an Alabama woman myself, I discovered Zelda Fitzgerald separately from her husband in my research on female Southern artists and 'famous' people from my state. I think this allowed me a very unique and privileged perspective on both Scott and Zelda because I viewed them separately before I viewed them as entangled in a creative partnership. It truly allowed me to value them both independently before I began to dig into their legendary relationship, and I am very thankful for that perspective.

NVA: Can you see any specific connections between her approach to dance and her approach to literature since she was devoted to both arts?

VN: Now this is an excellent discussion that I hope will continue in scholarship on Zelda. In life and in her writing, Zelda was enchanted by the unanswerable questions, the fragment, and the surreal. However, ballet is none of those things. Ballet is fantasy, beauty and symmetry, and in my experience, classical ballet is a world that makes "sense." There is a right and wrong, and there is always an answer to the question. There are understandable patterns and often, every loose end is tied up. At the F. Scott Fitzgerald conference, there was an incredible panel with Meryl Cates on Zelda's dance background that was illuminating and inspiring to me. We talked about Zelda's relationship to ballet and her experience of it perhaps being tied to the pursuit of a world that made sense and a world of comfort that was associated with her youth and memories. Zelda trained in and performed ballet since she was very young, but after her marriage to Scott, she infamously picked back up with her training "late" in life, and to some this obsession with making up lost time in ballet training allegedly 'caused' her mental breakdown. Many associate Zelda's decline mental health with her devotion to ballet, which in my opinion is unwarranted. However, I couldn't help but wonder if Zelda would have pursued modern dance instead of ballet how her life and experience would have been different. Modern dance was booming and blooming in Zelda's time, and it is a form more associated with the 'unanswerable questions' of Zelda's fascination. It would also perhaps have been friendlier to her aging body and limitations. I know that Zelda was linked to some of the modern dance community, and particularly Isadora Duncan, whom many call the 'mother' of modern dance. Like Zelda's beautiful streamers of words, Duncan's movement followed organic succession of the body's instinct, celebrated freedom, and engaged in the divinely feminine. Duncan's philosophy was incredibly compatible with Zelda's. However, Duncan was notoriously unstable financially in her late dance career. Was this significant enough to Zelda to deter her modern dance pursuit? Also, was modern dance just not socially where Zelda wanted to be? Was it not yet the "high brow" or rooted art form in which she wanted to prove herself and gain recognition? Was it not the dance form in which she felt this unexplainable 
attachment to the divine transcendence of time? Was modern dance not associated to the lost youth and innocence that maybe she was trying to internally recreate in an external world that was becoming unsteady and unpredictable for her? Would modern dance just not pay enough to financially support her life and gain her the independence she was seeking? It's interesting to think about, and perhaps scholars way smarter than me can answer these questions!

NVA: Your latest piece, called Three Ballerinas, was inspired by Zelda's eponymous sketch (drawn perhaps during one of her stays in mental hospital?). Could you explain how you got to work on this particular sketch, and how important it is, in your opinion, in Zelda's career?

VN: My senior year of college, I went to the Fitzgerald Museum in Montgomery, Alabama for the very first time. I was immediately enchanted by their collection and presentation of two vibrant life stories. Zelda's letter and art work were particularly resonating to me, but I remember walking in the very back room and seeing Zelda's "Three Ballerinas" for the very first time. To avoid a cliche, this was truly a life changing moment for me. As a dancer myself, I gazed at the sketch of these three grotesque ballerinas with their swollen arms and legs, proud chests, and unidentifiable faces. Dancers had never been portrayed in a way that understood me as much as that sketch did. I began to dig into her legacy, and like so many others found myself feeling an unexplainable, magnetic connection to Zelda. She understood me without even knowing me. In my work, Three Ballerinas: A Moving Sketch we interpret Zelda Fitzgerald's sketch, "Three Ballerinas" to illustrate the relationship between the three facets of a singular entity: mind, body, and spirit. Though this narrative focuses on the life and legacy of Zelda Fitzgerald, this is a universal story because each of us understands the journeys between the harmony and discord of our three inner selves.

Not only do these journeys have a direct impact on identity expression and the experience of our internal world, these journeys manifest in our external world and relationships. Immediately from the sketch, some things that inspired this dance work were Zelda's use of proportion. We interpret the shrunken heads to represent a loss of identity. All at once, Zelda sketches for us the sadness of feeling unseen and faceless. She writes about this in her work often, and we all understand in a specific and a universal sense the tragedy in loss of identity. However... I don't think that's the period at the end of a sentence. I believe Zelda shows us another layer to this. The heart center, soul, or spirit of these dancers is swollen, and the chests are proud and open. You can almost feel the ballerinas breathing, filling their lungs east to west. Our eyes are drawn to these wide chests - the heart center - before we even notice there are no faces on the figures. When I am dancing, I am not Victoria Niblett, a girl from a small town in Alabama that gets nervous every time she walks into a room because she doesn't know where she fits or who she is. When I'm dancing, I am spirit forward. You see my heart - not whatever shell of identity has been flimsily constructed. In Zelda's experience with dance, I believe she understood this. Another significant aspect of this sketch is the absence of grandeur and opulence that usually accompanies the ballet. Ballet is the highest brow of performance, with tutus and jewels and crowns, and pins, and pointe shoes. These dancers are not costumed. They are not adorned. They are represented not as performers, but as human beings breaking the idea that the dancer and the person cannot be separated. In fact, she might be asserting the more you dance, the more you begin to connect to that ultimate humanity - thinking about the costumes almost dripping and unraveling 
away. Zelda's experience with dance could very well have been subconsciously motivated by this desire for a connection between mind, body, spirit, and the external world - stripping down to humanity and nature. Finally, I'd like to acknowledge the swollen hands of these dancers. For the purpose of this work, I see the swollen hands as representational of hard work. Zelda acknowledged how hard ballet was, and we all know of her intense dedication and practice rituals. A carpenter, painter, writer, or sculptor works with their hands crafting and making something beautiful that is an extension of themselves. However, dance has no tangible fixation of work. Merce Cunningham, a modern dance pioneer, once said "You have to love dancing to stick to it. It gives you nothing back, no manuscripts to store away, no paintings to show on walls and maybe hang in museums, no poems to be printed and sold, nothing but that fleeting moment when you feel alive. It is not for unsteady souls." Zelda's sketch, "Three Ballerinas" with the swollen hands representational of a hard days work perfectly encompasses this idea.

In the greater scope of her career, perhaps the sketch itself is not "significant" but I found it an incredibly unifying piece involving her inner world, her public legacy, and her personal experience of a vibrant, too short life.

NVA: You mentioned dance as « innovative storytelling ». How far does dance - or at least your own dance - actually tell stories? How innovative can it be?

$\mathrm{VN}$ : At each performance, we provide programs and digital programs to our audience. To promote accessibility and context, we include educational materials in each program with the opportunity to "dive deeper" by presenting springboard sources to audience members. We hope these sources make it easier for audiences to expand their engagement with the subject matter. We understand and hope that dance can be used as a vehicle for literature, history, and other ideas.

To help our variety of audiences connect to our mission, we include a key to "decoding the dancing." Most of our audience members are not technically trained dancers or choreographers, and we want to empower them with knowledge on how to engage with dance in a vocabulary that is familiar and digestible. This allows audience members an ownership and confidence in viewing the dance work as an active audience, breaking the fourth wall of performance and including themselves in the production.

Just as reading literature through different lenses, dance has this same capacity. For example, some representational elements to look for in dance are similar to things you will already look for in literature: repetition, tone, and metaphor. In dance, there is in addition use of gestures that represent ideas. For example, we wave hello, rock a baby, or say I'm sleepy in our every day lives to represent ideas without using words. It's a form of 'body language' that is representational in nature. In crafting this work, we expand and abstract on this idea.

As far as innovation, I don't think something owned and within us all like movement and dance can ever truly be innovative because it's universal and natural. However, I believe that dance as a communication tool in telling stories about the specific can inspire innovative understandings of a story that humanize or contextualize it in an entirely new way. The beautiful thing about dance that is also a challenge is telling a story without using words. Dance communicates ideas, emotions, understandings, connections, and context that is often void of a translation to language. That means it 
can touch audience members and inspire their thoughts in an incredibly personal way that can be internalized and experienced without assigning or limiting it to words or categories.

NVA: How was your performance in Toulouse received by the audience mainly composed of Fitzgerald specialists (maybe not quite familiar with dance itself)? Did you get any comments on your work that struck you as particularly relevant or inspiring?

VN: Performing at the Fitzgerald Conference in Toulouse, still remains one of the best experiences of my life to date. We performed in a space absent of a proscenium stage divide, so we were on the level of the audience, breathing and moving with the audience in a way that was incredibly resembling interpersonal communication rather than performance. I remember dancing and experiencing the piece, but quite literally feeling the eyes and focus of the audience that broke the 'fourth wall' experience many dance/ theatre performances have. Instead of a one-way 'projection' After our work, we received a standing ovation, and some of the audience members even had intense emotional reactions or cried.

In personal feedback, I was fortunate to receive many positive responses, but one that resonated with me was from a woman that said, 'I cannot explain it, but I truly felt that.' It really resonated with me, and was one of the best reactions I have received because it was exactly my goal. I want it to be an experience beyond words that seems so distinctly personal and universal all at the same time. I suppose one of my goals in my career as a whole is proving that dance is not a 'separate' experience from humanity. It is not a 'high brow' art only available on proscenium stages and to a specific type of audience or 'correctly' experienced by a niche group of people. I don't believe there's a 'pure' or a 'diluted' dance experience. Yes, I always avoid commodification and appropriation out of my core values as an artist and human, but my point is that I don't associate dance itself and the experience of it as an 'exclusive' practice. I want people to acknowledge that dance and movement is the ultimate expression of humanity and connection to our universe. We are works of art after all, and dance is in the very makeup of our natural world. I often say that dance is the greatest expression of humanity because we are in a world that is moving. We live in a moving world full of rhythm - our hearts have beats, our oceans have tides, our earth is in orbit, our elements like wind and water move and shape the world around us. Our world is moving, and a way to connect with it is to just join in the dance!

\section{INDEX}

Mots-clés: chorégraphie, danse contemporaine, Jellybean Dance Collective, littérature, Zelda Fitzgerald

Keywords: choreography, contemporary dance, Jellybean Dance Collective, literature, Zelda Fitzgerald

Subjects: Music, Dance 


\section{AUTHORS}

\section{NATHALIE VINCENT-ARNAUD}

Professeur

Université Toulouse Jean-Jaurès

nathalie.vincent-arnaud@univ-tlse2.fr 